\title{
Isolation and Molecular Characterization of Cry Gene for Bacillus thuringiensis Isolated from Soil of Gaza Strip
}

\section{Azme Dagga ${ }^{1}$, Mohamed Abdel Aziz ${ }^{2}$, Abed Al'raoof Al Amnama ${ }^{3}$, Mervat Al-Sharif ${ }^{4}$ and Mahmoud El Hindi ${ }^{*}$}

${ }^{1}$ Microbiology, ERRC, Islamic University of Gaza, Palestine

${ }^{2}$ Microbiology, Botany Department, Faculty of Science, Suez Canal University Ismailia, Egypt

${ }^{3}$ Microbiology, Department of Medical and laboratories sciences, Islamic University of Gaza, Palestine

${ }^{4}$ Microbiology, Faculty of Education, Alexandaria University, Egypt

${ }^{5}$ Microbiology Lab, Department of Biology and Biotechnology, Islamic University of Gaza, Palestine

*Corresponding author

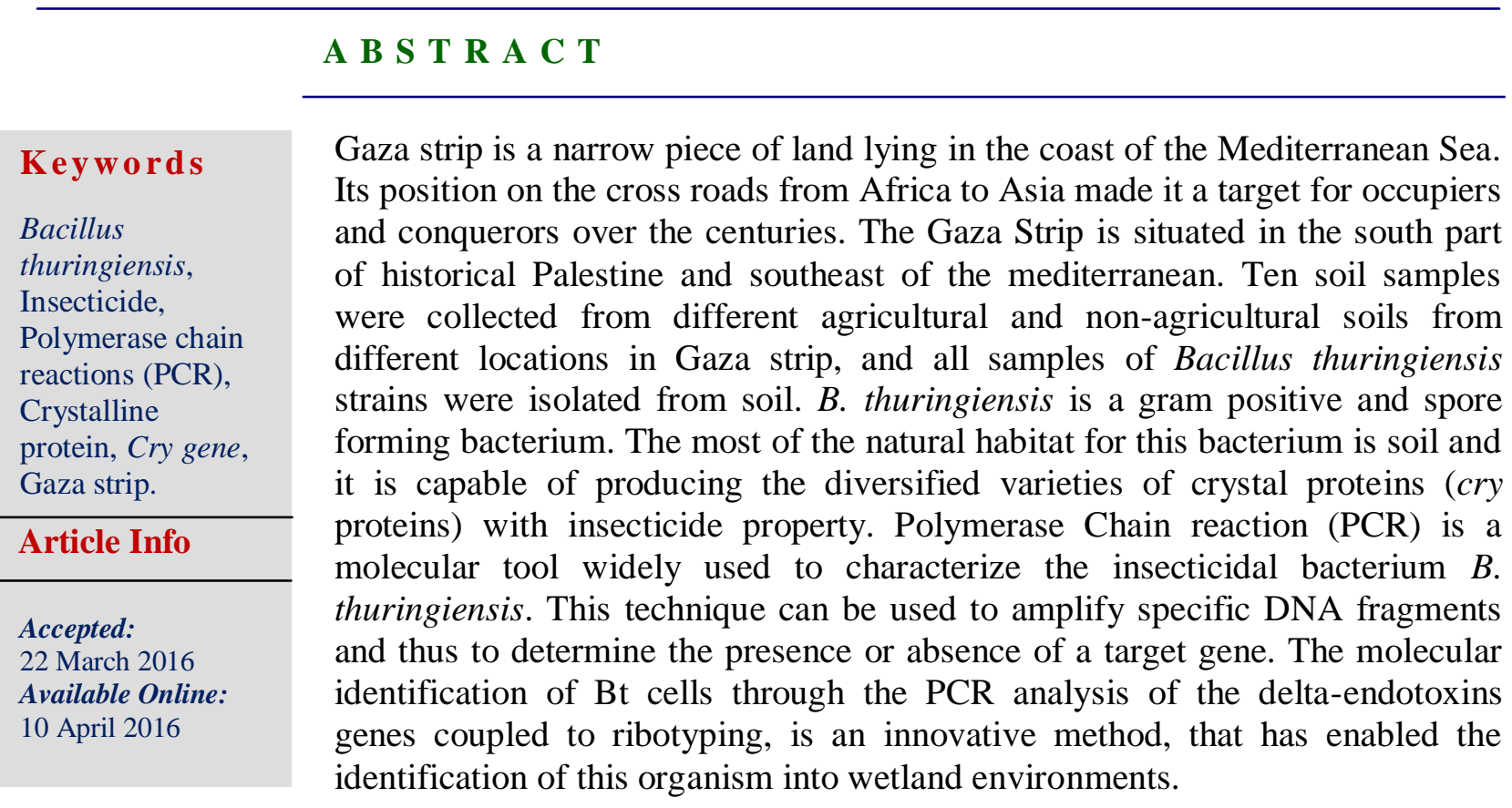

\section{Introduction}

Bacillus thuringiensis, insecticide, polymerase chain reactions (PCR), crystalline protein, Cry gene, Gaza strip. Bacillus thuringiensis (Bt) is a rod-shaped, gram-positive, facultative anaerobic, and spore-forming bacterium (Konecka et al., 2007). During sporulation, it produces insecticidal proteins, which are deposited within the sporangium as crystalline aggregates (Crickomre et al., 1998; 
Helgason et al., 1998). Parasporal crystals known as $\delta$-endotoxins, which are not produced by other species it resembles, namely $B$. cereus, $B$. mycoides, and $B$. anthracis (Koneman 1997; De Respinis et al., 2006; Soberon et al., 2007; Bizzarri and Bishop, 2008). These d-endotoxins are toxic to a great number of insects and turns $\mathrm{Bt}$ into a valuable tool to be used in the Insect Pest Management (IPM) (Valicente \& Lana, 2010). Some of which are toxic to a high number of insect species of the orders lepidoptera, Diptera and Coleoptera, in addition to a few Hemiptera (MacIntosh et al., 1990; Bravo et al., 2007; Porcar et al., 2009; Palma et al., 2014), and Nematoda (Wei et al., 2003). When orally ingested by insects, this crystal protein is solubilized in the midgut, forming proteins called deltaendotoxins. The toxicity of these crystals to the insects is determined by the presence of the specific receptors in the midgut epithelium (Bravo et al., 2007). There are two types of N-endotoxins: the highly specific Cry (from crystal) toxins which act via specific receptors and the non-specific Cyt (cytolytic) toxins, with no known receptors. Both families of toxins are classified exclusively on the basis of their amino acid sequence identity. Genes encoding these proteins (cry genes) were among the first to be used in genetic engineering of plants for enhanced insect resistance (Roh et al., 2007). Cry proteins have been used as bio-pesticide sprays on a significant scale against agricultural pests for more than 30 years, and their safety has been demonstrated, and he cry gene content of $B$. thuringiensis strains is known to be related to the toxicity (Federici et al., 2006), and the identification of cry genes by means of PCR has been exploited to predict insecticidal activities of the strains and to determine the distribution of cry genes within a collection of $B$. thuringiensis strains (Porcar \& Juárez-Pérez, 2003; Bozlağan et $a l ., 2010)$.

Different methods have presented to isolate the $B$. thuringiensis which are as following: Polymerase Chain Reaction (PCR), Southern blotting, serotyping and Bioassay method (Porcar \& Juárez-Pérez, 2003).

Current detection and identification methods of crystal genes (Cry) of B. thuringiensis which isolated form soil of Gaza strip based on PCR was executed for the first time by (Porcar \& Juárez-Pérez, 2003; Bozlağan et al., 2010). PCR is a fast and accurate method for identification of the unknown cry genes with new insecticidal activity. In the recent decades, PCR has been used extensively in order to determine the content of cry gene from the $B$. thuringiensis strains. As yet, more than 100 pairs of specific and different primers have been designed to identify the cry gene subsets (Porcar \& Juárez-Pérez, 2003). The aim of the current study was to develop a standardized and universally applicable molecular method for the detection of $\mathrm{Bt}$, which could be directly applied to colonies grown on agar medium.

\section{Materials and Methods}

\section{Materials}

All media, Primers, Kits, chemicals and reagents were purchased from various suppliers and are prepared according to manufacturer's recommendations shown in table 2.1 .

\section{Methodology}

\section{Soil Sample Collection}

Ten soil samples were collected from different agricultural and non-agricultural soils from Gaza strip (Rafah, wadi Gaza, Khanyunes, Abbasan, Gaza - Alshikh 
ejleen, Gaza - Islamic university, chicken farm soil, mint farm soil, Citrus farm soil). About 25 grams of top soil (after removed 2 $\mathrm{cm}$ of soil surface) were collected in a sterile cup, labeled with date and source of collection. Transported to the laboratory and processed within 2 hours of collection.

\section{Cultural Characterization}

The selected isolate was plated onto the surface of $B$. thuringiensis chromogenic agar and incubated for 24 hours at $30{ }^{\circ} \mathrm{C}$. Plates were inspected for growth and colony morphology (size, color and texture) were noted.

\section{Microscopic Examination}

For Gram Stain: A smear was prepared and air-dried, fixed and stained with gram staining reagents. In short, smears were flooded with crystal violet for one minutes and rinsed with water. Gram's Iodine was added for one minutes and rinsed with water. Ethanol was used to decolorize smears for not more than 20 seconds and washed with water. Finally, safranin was added for 30 seconds. Slides were rinsed and plotted onto absorbent tissue and examined under the high and oil immersion objectives. Gram stain was used to determine gram reaction and the shape of the bacterial isolates under microscope.

For Spore Staining (Schaeffer \& Fulton`s): A smear was prepared as previously described. The entire slide was flooded with Schaeffer \& Fulton`s Spore Stain A solution (malachite green). The slide was steamed for 5 minutes and rinsed under running tap water. The slide was counterstained with Schaeffer \& Fulton`s Spore Stain B solution (safranin) for 30 seconds. Slides were rinsed and plotted onto absorbent tissue and examined under the oil immersion objectives.

\section{Enrichment on Selective Medium}

One gram of soil sample placed in $9 \mathrm{ml}$ of sterile saline, vortexed for one minute, and heated at $80^{\circ} \mathrm{C}$ for five minutes to eliminate all vegetative bacterial and fungal spores. A loopful from the heated vortexed soil is streaked on R \& F Bacillus cereus / Bacillus thuringiensis Chromogenic Plating Medium. Plates are incubated at $37{ }^{\circ} \mathrm{C}$ for 48 hours. Suspected colonies characterized by pale blue colored on chromogenic media are then sub cultured for testing their larvicidal activity before an identification process is initiated.

\section{DNA Isolation from Bt}

Bacillus thuringiensis strains were activated in NA at $37^{\circ} \mathrm{C}$ overnight. The total DNA isolation by using Patho Gene-Spin TM DNA/RNA Extraction Kit (iNtRON Biotechnology, Korea) is designed for rapid and sensitive isolation of DNA or RNA from a variety of pathogen such as virus, bacterium and etc.

\section{Oligonucleotide PCR Primers}

Semi-conserve PCR reaction with CU-F and CU-R primers (synthesis by Hy Laboratories Ltd.) (Table 2.1) was carried out in the volume of $25 \mu \mathrm{l}$ containing 2 units of TaqDNA polymerase, enzyme buffer (50 mMof $\mathrm{NaCl}, 10 \mathrm{mM}$ of Tris, $\mathrm{pH} \mathrm{8.3),} 2$ mMof $\mathrm{MgCl} 2,0.25 \mathrm{mMdNTP}, 10$ pmol of each one of primers and $200 \mathrm{ng}$ of DNA. After an initial 5 min denaturation at $94^{\circ}, 35$ cycles of $95^{\circ} \mathrm{C}$ for $40 \mathrm{sec}, 52^{\circ} \mathrm{C}$ for $60 \mathrm{sec}$, $72^{\circ} \mathrm{C}$ for $40 \mathrm{sec}$ was carried out, followed by a 5 min extension at $72^{\circ} \mathrm{C}$ using a thermalcycler (Biometra, Germany).The 180-200 bp amplified product was electrophoresed on $2 \%$ agarose gel. 


\section{Results and Discussion}

\section{Isolation of $\boldsymbol{B} t$ from Soil of Gaza Strip}

After removing the surface layer of soil, collection of 100 gram has been done from the aforementioned areas in sterile bottles of polyethylene then proper storage in refrigerator were done and these samples shown in Figure 3.1

\section{Cultural Characterization}

The cultural characteristics of the suspected Bacillus thuringiensis isolates were examined. Generally, colonies were white to cream in color, tend to have large frosted glass appearance, initially, but may become opaque. Some colonies were mucoid in nature, others brittle. The isolates are Grampositive, spore formers and motile. The spore is found in the center of the cell. The shape of spores is ellipsoidal. All isolates produced crystal proteins with various forms and size, this result presented in Figure 3.2

\section{Microscopic Examination}

For Gram Stain: Slides were treated by gram stain reagents, and examined under the high and oil immersion objectives. $B t$ appeared as gram positive bacilli and presented in Figure 3.3.

For Spore Stain: Slides were treated by Schaeffer \& Fulton's reagents, and examined under the oil immersion objectives. Green free spores as well as centrally located spores were detected, and illustrated in Figure 3.4.

\section{Enrichment on Selective Medium}

This selective media that contains nutrient broth and 0.25 gram of sodium acetate used as effective media for enrichment of $B t$ bacteria. Selective media of the $B t$ was made using (Sigma-HiCrome Bacillus Agar) as effective media, and the enrichment of $\mathrm{Bt}$ shown in Figure 3.5

Table.2.1 List of Media, Chemicals and Reagents used in this Study

\begin{tabular}{|c|c|c|c|}
\hline & Item Name & Manufactures & Country \\
\hline 1 & $\begin{array}{r}\text { Patho Gene-Spin }{ }^{\mathrm{TM}} \text { DNA/RNA Extraction } \\
\text { Kit }\end{array}$ & iNtRON Biotechnology & KOREA \\
\hline 2 & Master Mix 2X & $\begin{array}{r}\text { Thermo Fisher Scientific } \\
\text { Inc }\end{array}$ & USA \\
\hline 3 & Ladder $100 \mathrm{bp}$ & $\begin{array}{r}\text { Thermo Fisher Scientific } \\
\text { Inc }\end{array}$ & USA \\
\hline 4 & Agarose & SIGMA- Aldrish & USA \\
\hline 5 & $\begin{array}{r}\text { Primer CU-F } \\
\text { 5'- GGA TTG GAA TGG GAA ACA -63 }\end{array}$ & \multirow{2}{*}{ Hy Laboratories Ltd. } & \multirow{2}{*}{ Israel } \\
\hline 6 & $\begin{array}{r}\text { Primer CU-R } \\
\text { 5'- AAA TAG CCG CAT TGA CAC-'3 }\end{array}$ & & \\
\hline 7 & Nutrient Agar & HiMedia & India \\
\hline 8 & Broth Agar & HiMedia & India \\
\hline
\end{tabular}


Table.2.2 Sequences of the Cry genes Primers used for PCR Amplification

\begin{tabular}{|c|c|c|c|c|}
\hline \# & Primer Sequences (5 to 3) & $\begin{array}{l}\text { Annealing } \\
\left(\mathbf{C}^{0}\right)\end{array}$ & Size (bp) & References \\
\hline 1 & $\begin{array}{c}\text { Primer CU-F } \\
\text { 5'- GGA TTG GAA TGG GAA ACA -`3 }\end{array}$ & \multirow{2}{*}{$52 C^{0}$} & \multirow{2}{*}{$180-200$ bp } & \multirow{2}{*}{$\begin{array}{l}\text { (Porcar \& Juárez- } \\
\text { Pérez, 2003; Bozlağan } \\
\text { et al., 2010) }\end{array}$} \\
\hline 2 & $\begin{array}{c}\text { Primer CU-R } \\
\text { 5'- AAA TAG CCG CAT TGA CAC-'3 }\end{array}$ & & & \\
\hline
\end{tabular}

Figure.3.1 Soil Samples that Collected for Bacillus thuringiensis Isolation

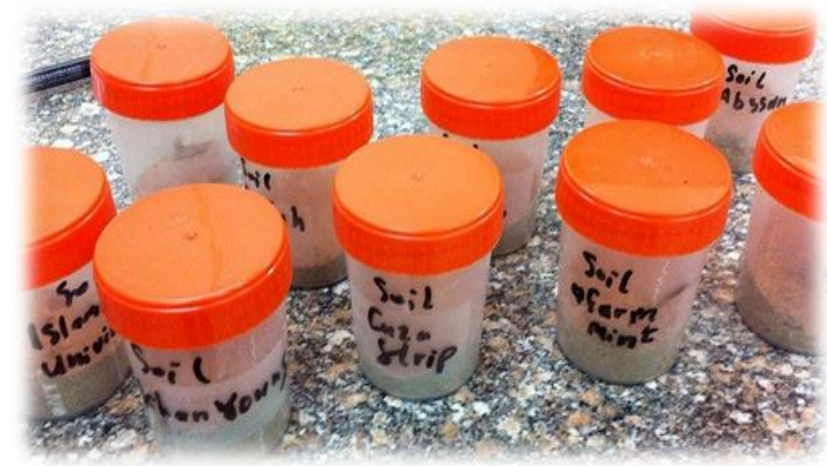

Figure.3.2 Colonies of Bacillus spp. on Nutrient Agar Medium

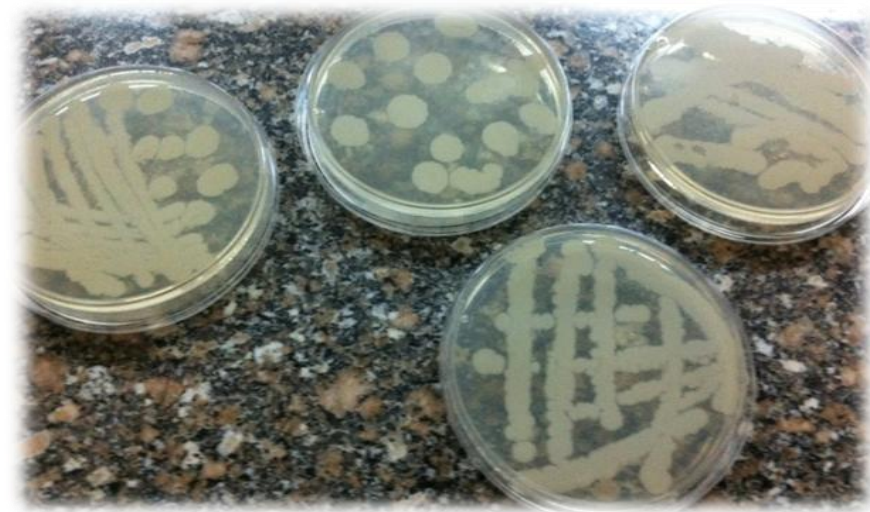

Figure.3.3 Bt. Stained by Gram Positive (Purple) 1000X

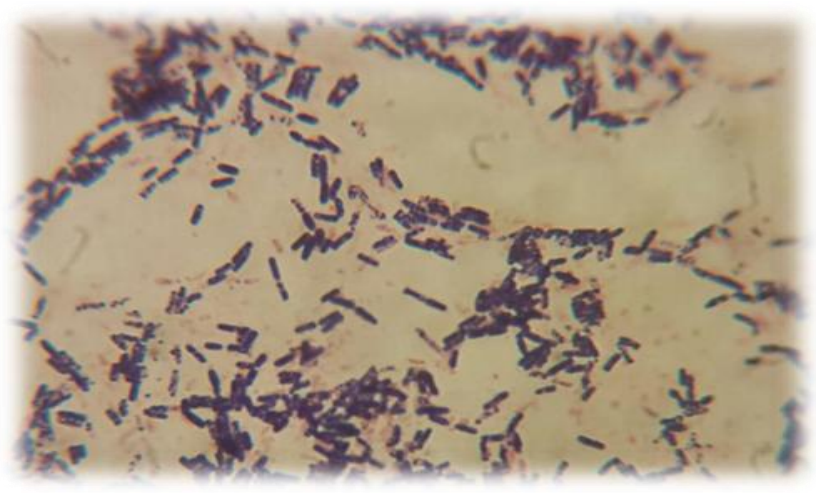


Figure.3.4 Bt. Spore Staining (Schaeffer \& Fulton`s)

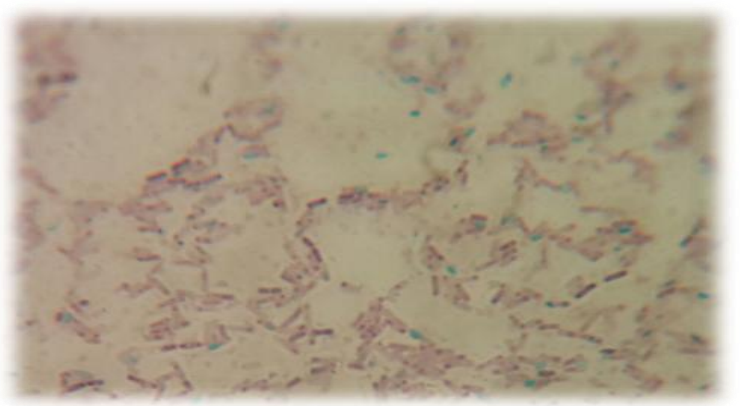

Figure.3.5 Subculturing on Selective Media Containing on Sodium Acetate

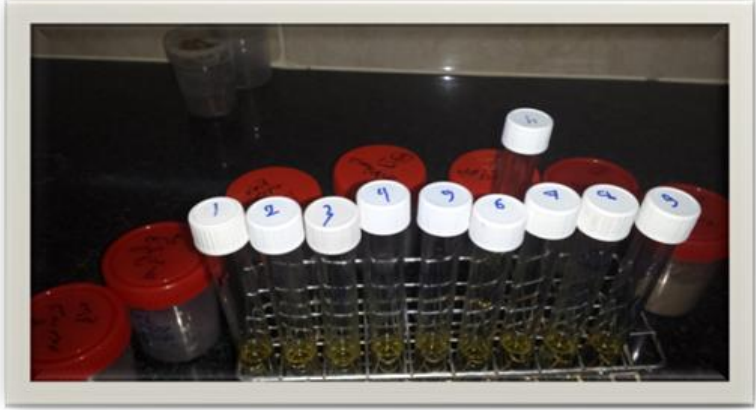

Figure.3.6 Result of Amplification of Cry Gene on the Bacterium Sample Isolated from the Soil of Gaza Strip

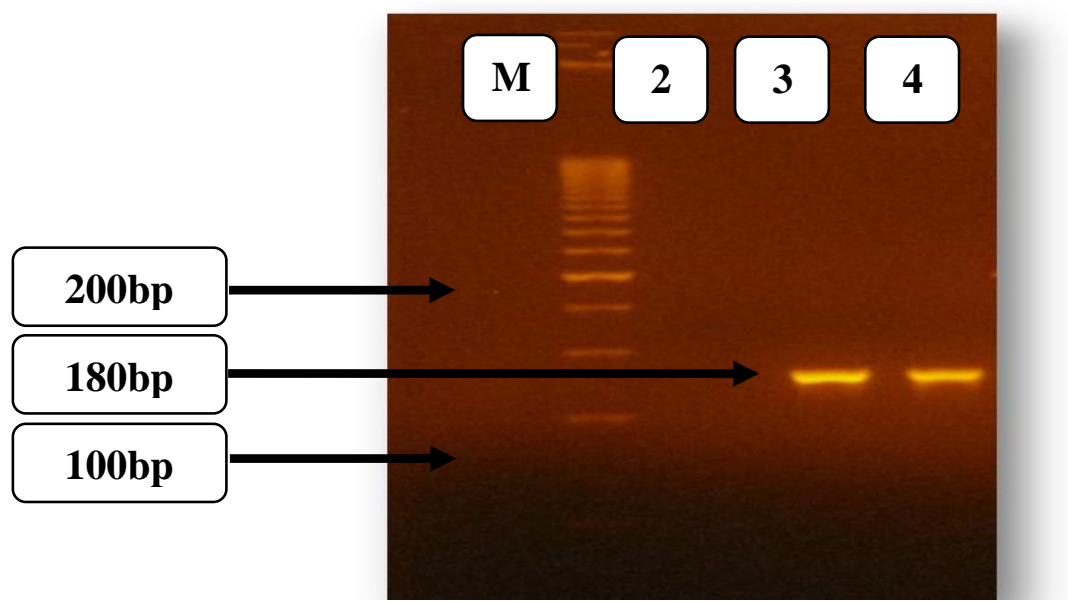

Line 1, size Marker 100 to 3000 bp, Line 2, as negative control by using E. coli. fermentase. Line 3, Cry gene positive amplification by semi conserve PCR for B. thuringiensis israelensis. Line 4, Cry gene positive amplification by semi-conserve PCR for samples of $B$. thuringiensis isolated from Gaza strip

\section{Molecular Identification of Cry Gene}

In all, 10 Bacillus spp. isolates were obtained from the soil samples from different regions of Gaza strip using selective media. Total DNA was isolated and analyzed by PCR using cryl general primers. Of the 10 isolates, 2 carried the cryl gene. Plasmids of those strains were isolated and their insecticidal activity and the result of amplification of Cry gene presented in figure 3.6

In the present study 10 different putative Bacillus spp. isolates were obtained from soil in different regions of Gaza strip, and 
the presence of $B$. thuringiensis strains. Morphological characterization and Gram staining of the isolates were carried out. Although colony morphology of the isolates was similar to that of the reference strain (BtI), morphological characterization only is not reliable for identification of isolates. As different $\mathrm{Bt}$ isolates might have a similar colony morphology, molecular characterization of the isolates is better than either serological or morphological characterization (Iriarte et al., 2000).

Cry proteins are encoded by cry genes that are frequently carried on plasmids; to date, nearly 300 cry genes have been identified and classified into 51 groups and subgroups on the basis of amino acid sequence similarity (Ye et al., 2012).

B. thuringiensis, which tested in this work, were also analyzed for the presence of cry gene sequences. The designed primers are specific to Cry gene, resulting in the amplification of a DNA fragment of around 180-200bp as PCR product, and the results for amplification of cry gene for molecular identification of $\mathrm{Bt}$ in (Porcar \& JuárezPérez, 2003) support the result in the presence study.

Comparative analyses of cry genes, amplification with $\mathrm{CU}$ primers, plasmid pattern and protein profile allowed the clear differentiation of the evaluated strains. It may also help in the establishment of a new subspecies-level classification of Bt. Due to this discrimination, these analysis can be an useful tool in the characterization of $\mathrm{Bt}$ strains, something highly valuable in intellectual property claims.

\section{Acknowledgement}

The authors are very grateful to all staffs in Department of Biotechnology, Islamic University - Gaza, Palestine for financial supporting and providing excellent research facilities.

\section{References}

Bizzarri, M.F., Bishop, A.H. 2008. The ecology of Bacillus thuringiensis on the Phylloplane: colonization from soil, plasmid transfer, and interaction with larvae of Pieris brassicae. Microb. Ecol., 56: 133-139.

Bozlağan, I., Ayvaz, A., Öztürk, F., Acik, L., Akbulut, M., Yilmaz, S. 2010. Detection of the cry1 gene in Bacillus thuringiensis isolates from agricultural fields and their bioactivity against two stored product moth larvae. Turkish J. Agri. Forestry, 34(2): 145-154.

Bravo, A., Gill, S.S., Soberón, M. 2007. Mode of action of Bacillus thuringiensis Cry and Cyt toxins and their potential for insect control. Toxicon, 49: 423-435.

Crickmore, N., Zeigler, D.R., Feitelson, J., Schnepf, E., Van Rie, J., Lereclus, D., Baum, J., Dean, D.H. 1998. Revision of the nomenclature of the Bacillus thuringiensis pesticidal crystal proteins. Microbiol. Mol. Biol. Rev., 62: 807813.

De Respinis, S., Demarta, A., Patocchi, N., Luthy, P., Peduzzi, R., Tonolla, M. 2006. Molecular identification of Bacillus thuringiensis var. israelensis to trace its fate after application as a biological insecticide in wetland ecosystems. Lett. Appl. Microbiol., 43: 495-501.

Federici, B.A., Park, H.W., Sakano, Y. 2006. Insecticidal protein crystals of Bacillus thuringiensis. In: Inclusions in Prokaryotes (Ed. JM Shively), SpringerVerlag, Berlin-Heidelberg, pp. 195235.

Helgason, E., Caugant, D.A., Lecadet, M.M., Chen, Y., Mahillon, J., Lo“vgren, A., Hegna, I., Kvaloy, K. et al. 1998. Gene diversity of Bacillus cereus/B. 
thuringiensis isolates from natural source. Curr. Microbiol., 37: 80-87.

Iriarte, J., Porcar, M., Lecadet, M.M., Caballero, P. 2000. Isolation and characterization of Bacillus thuringiensis strains from aquatic environments in Spain. Curr. Microbiol., 40: 402-408.

Konecka, E., Kaznowski, A., Ziemnicka, J., Ziemnicki, K. 2007. Molecular and phenotypic characterisation of Bacillus thuringiensis isolated during epizootics in Cydia pomonella L. J. Invertebr. Pathol., 94: 56-63.

Koneman, E.W., Allen, S.D., Janda, W.M., Schreckenberger, P.C., Winn, W.C. 1997. Color Atlas and Textbook of Diagnostic Microbiology, fifth edn. Lippincott, Philadelphia.

MacIntosh, S.C., Stone, T.B., Sims, S.R., Hunst, P.L., Greenplate, J.T., Marrone, P.G., Perlak, F.J., Fischhoff, D.A., Fuchs, R.L. 1990. Specificity and efficacy of purified Bacillus thuringiensis proteins against agronomically important insects. $J$. Invertebr. Pathol., 56: 258-266.

Palma, L., Muñoz, D., Berry, C., Murillo, J., Ruiz de Escudero, I., Caballero, P. 2014. Molecular and Insecticidal Characterization of a Novel CryRelated Protein from Bacillus Thuringiensis Toxic against Myzus persicae. Toxins, 6: 3144-3156.

Porcar, M., Caballero, P. 2000. Molecular and insecticidal characterization of a Bacillus thuringiensis strain isolated during a natural epizootic. J. Appl. Microbiol., 89: 309-316.
Porcar, M., Juárez-Pérez, V. 2003. PCR-based identification of Bacillus thuringiensis pesticidal crystal genes. FEMS Microbiol. Rev., 26(5), 419-432.

Porcar, M., Grenier, A.M., Federici, B., Rahbe, Y. 2009. Effects of Bacillus thuringiensis $\delta$-endotoxins on the pea aphid (Acyrthosiphon pisum). Appl. Environ. Microbiol., 75: 4897-4900.

Roh, J.Y., Jae, Y.C., Ming, S.L., Byung, R.J., Yeon, H.E. 2007. Bacillus thuringiensis as a specific safe and effective tool for insect pest control. J. Microbiol. Biotechnol., 17: 547-559.

Soberon, M., Fernandez, L.E., Perez, C., Gill, S.S., Bravo, A. 2007. Mode of action of mosquitocidal Bacillus thuringiensis toxins. Toxicon, 49: 597-600.

Valicente, F.H., Lana, U.G.D.P. 2010. Molecular characterization of the Bacillus thuringiensis (Berliner) strains 344 and 1644, efficient against fall armyworm Spodoptera frugiperda (JE Smith). Revista Brasileira de Milho e Sorgo, 7(03).

Wei, J.Z., Hale, K., Carta, L., Platzer, E., Wong, C., Fang, S.C., Aroian, R.V. 2003. Bacillus thuringiensis crystal proteins that target nematodes. Proc. Natl. Acad. Sci. USA, 100: 2760-2765.

Ye, W., Zhu, L., Liu, Y., Crickmore, N., Peng, D., Ruan, L., Sun, M. 2012. Mining new crystal protein genes from Bacillus thuringiensis based on mixed plasmidenriched genome sequencing and a computational pipeline. Appl. Environ. Microbiol., 78: 4795-4801.

\section{How to cite this article:}

Azme Dagga, Mohamed Abdel Aziz, Abed Al'raoof Al Amnama, Mervat Al-Sharif and Mahmoud El Hindi. 2016. Isolation and Molecular Characterization of Cry Gene for Bacillus thuringiensis Isolated from Soil of Gaza Strip. Int.J.Curr.Microbiol.App.Sci.5(4): 659-666. doi: http://dx.doi.org/10.20546/ijcmas.2016.504.075 